mentioned in the records of similar cases, and they have been regarded by some authors as tubercular, by others as probably syphilitic. In this case, at least, the presence of the tubercle bacillus in certain of the nodules affords substantial proof of their true nature. Without this proof it would have been impossible to say whether they were syphilitic or tubercular, if judged from minute structure alone. The position of the nodules here is not a common one for tuberculosis (primarily), and it is highly probable that they have arisen in tissue previously altered by chronic inflammatory changes, and being formed under syphilitic influence, have become quickly enveloped by a capsule of fibrous tissue.

\title{
LONGEVITY AND HEART DISEASE.
}

By JAMES ADAM, M.B., F.F.P.\& S. G., HaMilton.

ThE Rev. John Inglis, of Hamilton, "father" of the United Presbyterian Church, who last June completed the sixtieth year of his ministry, and who died on the 4th ult., was a remarkable patient. He had reached his ninety-sixth year, and was thus the oldest man in Hamilton; yet fully fifty years ago he was rejected by an insurance company on account of heart disease. Twenty-seven years ago the heart symptoms became very pronounced. He had violent attacks of angina, accompanied by dyspnca, pallor, and clammy sweat. He would have to stop in quite a short service owing to dyspnœa; and his family were prepared for his death at any moment. Professor Gairdner, who saw him in 1870, absolutely forbade him to take part in any of his duties or to incur any exertion or excitement whatever. Even the effort of saying grace, which nevertheless he regularly did, became too much for him, and there was always a long pause in the middle of it for breath. He continued, however, to be able to move about till a week before death, and so lately as two years ago was able to appear in church, though he took no part in the service. Fifteen years ago he had œedema of the lower extremities; this disappeared in a few weeks, and never returned. Eight years ago he had a severe carbuncle between the scapulæ, and from about that time the angina troubled him much less. During the last few years he had frequent attacks of bronchitis; two years ago he fell downstairs; in March last he had influenza; yet he recovered perfectly in 
each case. The excitement connected with the addresses presented to him on the sixtieth anniversary of his ministry, to one of which he managed to reply, proved too severe a tax on him. He caught cold, and, after being confined to bed five days, died on the 4th July.

Mr. Inglis was under my care only during the last few years, and my opportunities of examining him were limited by his feebleness, so that this account is necessarily imperfect. There was little, if any, enlargement of the heart; there was a V.S. murmur in the aortic area; no œdema. The pulse was regular, and of fair quality; the veins on his limbs stood out like cords. He was of spare build. He had slight difficulty in hearing; he could just discern the hands on the clock-face by looking closely. His intellectual qualities remained perfect, except for occasional lapses of memory regarding recent events. A placid temperament and careful nursing did much to prolong life.

This case simply goes to prove that a V.S. aortic murmur, of all organic murmurs, affords the most favourable prognosis. The presence of such a murmur makes it probable that the angina was due to thrombosis in a coronary artery. If so, it is probable that collateral circulation became established in the course of time; this is now known to be possible, as the coronary arteries have been shown to anastomose freely.

\section{GURRENT TOPICS.}

University of GLASGow-List of Degrees CONFERRED on 26TH JULY, 1894:-

Doctors of Medicine (M.D.)-I. With Commendation.-John M'Cubbin Johnston, M.A., M.B., C.M., Scotland (Thesis-“The Prognosis of Acute Lobar Pneumonia in the Pauper Class.")

II. Ordinary Degree.-James Alexander, M.B., C.M., Scotland (Thesis- "Abnormal Uterine Hæmorrhage, with Notes on Cases"); George Gore Gillon, M.B., C.M., Ireland (Thesis_-"Surgical Cases in Wellington Hospital, New Zealand"); Alexander Johnston, M.B., C.M., Scotland (Thesis - "Fifteen Cases of Diphtheria, with Remarks"); Duncan Macartney, M.A., M.B., C.M., Scotland (Thesis-"Excision of the Elbow Joint, with Thirty Cases in Illustration"); Ferdinand Rees, M.B., C.M., England (Thesis"Puerperal Embolism and Puerperal Thrombosis"); Oswald Rees, M.B., C.M., England (Thesis_ " On the Treatment of so-called Cases 